This work is licensed under Creative Commons Attribution 4.0 International (CC BY 4.0). [http://creativecommons.org/licenses/by/4.0/]

\title{
Wpływ rekreacyjnej aktywności fizycznej na społeczno-gospodarcze aspekty bezpieczeństwa narodowego w świetle literatury przedmiotu
}

Łukasz Bień | Uniwersytet Gdański

https://orcid.org/0000-0003-2576-7163

Słowa kluczowe:

bezpieczeństwo narodowe,

bezpieczeństwo

społeczne,

rekreacyjna aktywność fizyczna, zdrowie
Keywords:

national security, social security recreational physical activity, health

\section{Streszczenie}

Artykuł związany jest bezpośrednio z tematyką bezpieczeństwa narodowego w aspektach gospodarczych i społecznych i łączy wspomniane kwestie $z$ aktywnością fizyczną. Autor korzysta głównie z metody analizy literatury, zarówno naukowej, jak i autobiografii osób uprawiających sport, a także analizy tekstów źródłowych. Korzystając z wymienionych metod, scharakteryzowane zostały pojęcia podstawowe dla tekstu, tj. bezpieczeństwo narodowe oraz społeczne i gospodarcze, a także tematyka aktywności fizycznej. Pokrótce zobrazowany został wpływ, jaki wywiera aktywność fizyczna na życie współczesnego człowieka, poczynając od spojrzenia z punktu widzenia socjologii, przez psychologię, aż po wpływ na fizjologię organizmu, zarówno w aspektach pozytywnych, jak i negatywnych. Dokonano także analizy, w jaki sposób ujmowane są kwestie zdrowia w najistotniejszych (zdaniem Biura Bezpieczeństwa Narodowego) dokumentach dotyczących bezpieczeństwa narodowego. Następnie wykazano, jak istotny jest wpływ aktywności fizycznej, która pozostaje często powiązana z kwestiami zdrowia człowieka, z bezpieczeństwem gospodarczym i społecznym, m.in. przez niepośledni wpływ wywierany na wydatki na opiekę zdrowotną, a także wydajność pracy. Jednak wspomniano także o możliwym odwrotnym, tj. negatywnym wpływie, który sugerują niektórzy badacze.

\section{Impact of recreational physical activity on social and economic aspects} of national security in literature (Summary)

The topic of article is directly related to the subject of national security in economic and social aspects. It connects the above-mentioned issues with physical activity. In the article, the author uses mainly the method of analyzing scientific literature and autobiographical books of runners, as well as analysis of source texts. Taking advantage of the methods in question, the basic notions for the text such as national, social and economic security have been characterized. What is also depicted is the definition of a physical activity, which is further distinguished between amateur and professional one. In the following part, 
the influence of the physical activity on the life of a modern man from the sociological, psychological and physiological standpoint is indicated, both in positive and negative aspects (the problem of addictions). The author analyzed how health is treated in the most important (according to the National Security Bureau) document regarding national security. It has been proved how important the impact of physical activity is, which is often related to human health issues, with economic and social security, including the remarkable impact on health care expenditure as well as labor efficiency. However, the article also touches upon a possible reverse influence that some researchers suggest.

\section{Wstęp}

Bezpieczeństwo pozostaje niezmiennie, od początku bodaj rodzaju ludzkiego, jedną z podstawowych potrzeb człowieka. Kwestie bezpieczeństwa w szerokim zakresie wchodzą w zakres badań licznych nauk, m.in. nauk o obronności, zajmujących się aspektami związanymi ze "sztuką" wojenną, taktyką, strategią obronności, czy nauk o bezpieczeństwie, w sferze zainteresowania których pozostają szerokie kwestie dotyczące systemów bezpieczeństwa na różnych poziomach. Problematyka bezpieczeństwa w wielu odmiennych aspektach zajmuje też centralną pozycję w takich dziedzinach, jak nauki o polityce, socjologia, psychologia czy prawo, które to zajmują się bezpieczeństwem $w$ aspektach społecznym i gospodarczym.

Zgodnie z hipotezą postawioną na potrzeby niniejszego artykułu aktywność fizyczna obywateli wywiera korzystny wpływ na bezpieczeństwo narodowe, szczególnie w tytułowych wymiarach. Założono istnienie korelacji pozytywnej, tj. wzrostu poziomu bezpieczeństwa narodowego przy wzroście zaangażowania obywateli w aktywność fizyczną. Aby udowodnić założoną hipotezę, postawiono szereg pytań badawczych. Do najważniejszych należy pytanie o poziom aktywności społeczeństwa zbadanej za pomocą wydatków ponoszonych na aktywność. Kolejne pytania dotyczą wpływu aktywności fizycznej na poprawę poziomu zdrowia oraz jak kwestia zdrowia ujmowana jest w strategiach związanych z bezpieczeństwem, a w końcu, jaki wpływ poprawa dobrostanu fizycznego i psychicznego wywrze na bezpieczeństwo państwa. Postawiono także pytanie, jakie negatywne skutki dla bezpieczeństwa może przynieść pozostawanie aktywnym, szczególnie gdy nadużywana jest ta formy rekreacji.

W literaturze przedmiotu można odnaleźć publikacje dotyczące udziału profesjonalistów w różnego rodzaju zawodach sportowych'1. Istnieje także wiele publikacji i analiz dotyczących pozytywnego wpływu rekreacyjnej aktywności fizycznej na poziom

\footnotetext{
${ }^{1}$ Do literatury zagranicznej z tego zakresu należą np. publikacje Scotta Jurka łączące wątki biograficzne autora z poradami dotyczącymi treningu i odżywiania (Jurek 2012; 2018). Z literatury polskiej szczególnie interesująca wydaje się pozycja autorstwa Magdaleny Dołęgowskiej, jednej z najbardziej utytułowanych polskich biegaczek ultramaratonów i współorganizatorki ultramaratonu "Chudy Wawrzyniec" (Dołęgowska 2015).
} 
zdrowia fizycznego i psychicznego, do których sięgnął autor, a w licznych raportach Ministerstwa Sportu i Turystyki znajdują się badania dotyczące aktywności fizycznej obywateli naszego państwa w różnym wieku. Szczególnie cenny jest raport Ocena korzyści społecznych inwestycji w sport w odniesieniu do ponoszonych kosztów (Baran, Lis, Magda 2016), w którym przedłożono szereg istotnych analiz i prognoz związanych m.in. $z$ tematyką niniejszej pracy. Kwestie związane ze zdrowiem i jego oddziaływaniem na bezpieczeństwo społeczne państwa znaleźć można także w strategiach bezpieczeństwa narodowego RP z 2007 i 2013 roku, w Białej Księdze Bezpieczeństwa Narodowego Rzeczypospolitej Polskiej oraz w dokumentach strategicznych długoi średnioterminowych (jak Polska 2030. Trzecia fala nowoczesności. Długookresowa strategia rozwoju kraju czy też Strategia rozwoju kraju 2020). Nie udało się jednak odnaleźć w literaturze przedmiotu syntezy opisywanej literatury, dokumentów i szerszego zarysowania oddziaływania na siebie poszczególnych elementów systemu. Lukę tę autor postara się wypełnić w niniejszej pracy.

Jak się wydaje, obecnie często odchodzi się od klasycznego sposobu rozumienia bezpieczeństwa jedynie w aspekcie militarnym. Na przestrzeni wieków możemy dostrzec ewolucję pojmowania tego pojęcia. Tradycyjne koncepcje stosunków międzynarodowych akcentowały głównie czynnik militarny, obecnie podchodzi się do niego znacznie szerzej. Innym istotnym aspektem bezpieczeństwa państwa, który uległ znacznej ewolucji, jest przejście od rozumienia go w kontekście negatywnym, tj. braku zagrożeń dla państwowości, do rozumienia w kontekście pozytywnym, czyli - ogólnie rzecz biorąc - pewnego stanu sprzyjającego harmonijnemu rozwojowi państwowości. W literaturze przedmiotu można znaleźć wiele definicji bezpieczeństwa narodowego akcentujących jego różne oblicza.

Jedną z najbardziej wyczerpujących i holistycznych perspektyw proponują Ryszard Zięba i Justyna Zając, pisząc o zdolności „państwa i jego narodu (społeczeństwa) do zapewnienia pewności przetrwania (państwa jako instytucji, narodu jako grupy etnicznej, biologicznego przeżycia ludności), integralności terytorialnej, niezależności politycznej, stabilności wewnętrznej oraz jakości życia. Pewność ta jest kształtowana poprzez działania negatywne polegające na eliminowaniu zagrożeń zewnętrznych i powstających w ramach państwa oraz działania pozytywne zapewniające przetrwanie, posiadanie (tożsamość), funkcjonowanie i swobody rozwojowe państwa i narodu (społeczeństwa)" (Zięba, Zając 2010: 4).

Podstawową metodą badawczą, którą posłużono się w toku rozważań, jest analiza literatury dotyczącej tematyki pracy, tj. publikacji związanych z bezpieczeństwem narodowym, sportem w wymiarze rekreacyjnym i zawodowym w aspekcie fizjologicznym, medycznym psychologicznym i socjologicznym. Przeanalizowano badania dotyczące rekreacyjnej aktywności fizycznej, a także dokumenty źródłowe, tj. strategie i dokumenty związane z zapewnieniem bezpieczeństwa i harmonijnego rozwoju Polski. 


\section{Zdrowie obywateli jako element bezpieczeństwa państwa na podstawie wybranych dokumentów strategicznych}

Jednym z istotniejszych przedmiotów troski związanej z zapewnieniem bezpieczeństwa jest niewątpliwie zdrowie. Zdrowie jest pojęciem budzącym problemy definicyjne. Najprościej byłoby określić zdrowie jako brak chorób. Jednak tego rodzaju definicja negatywna nie ma żadnych wartości eksplanacyjnych i w toku rozważań naukowych posiada nikłą wartość. Ponadto wyżej wspomniana definicja nie ujmuje zdrowia jako procesu, który realizuje się w czasie i jest podstawą do rozwoju nie tylko jednostki, ale i w dalszej perspektywie całych społeczności. Zdrowie według Światowej Organizacji Zdrowia (WHO) określane jest jako „nie tylko całkowity brak choroby czy kalectwa, ale także stan pełnego fizycznego, psychicznego i społecznego dobrostanu" (Starzyńska-Kościuszko 2010: 324). Powyższa definicja charakteryzuje się wysokim stopniem ogólności i nie wyczerpuje niezwykle szerokiego pola pojęciowego związanego z poruszaną kwestią. Warto podkreślić relatywizm przy definiowaniu zdrowia, istotne są bowiem uwarunkowania związane z poziomem gospodarczym czy ogólnymi uwarunkowaniami otoczenia ${ }^{2}$. Jak wskazuje Jan Domaradzki, co do „koncepcji zdrowia i choroby (...) definicje, klasyfikacje i opis tych fenomenów muszą uwzględniać zmieniające się spektrum choroby w określonym czasie i warunkach społecznych" (Domaradzki 2013: 9-10), a nawet stawia tezę co do koncepcji zdrowia jako takiego, że „W równym stopniu co do świata natury przynależy ono do świata kultury” (Domaradzki 2013: 408). Zdaniem Aarona Antonovsky'ego, twórcy pojęcia salutogenezy, „, pomiędzy zdrowiem a chorobą istnieje kontinuum stanów, które należy rozumieć całościowo jako dynamiczny proces równoważenia wymagań i zasobów w toku konfrontacji ze stresem" (Antonovsky 1995: 7). O trudnościach w definiowaniu zdrowia piszą także Irena Heszen i Helena Sęk, które wspominają propozycje postulujące uwzględnienie dynamiki zdrowia i określają ją jako „dyspozycję umożliwiającą adaptacyjne funkcjonowanie w określonym środowisku bądź jako proces poszukiwania i utrzymywania równowagi między wymaganiami środowiska zewnętrznego i wewnętrznego a wysiłkami adaptacyjnymi" (Heszen, Sęk 2007: 59, 60). Margaret Dahlgren i Martin Whitehead wskazują na cały szereg czynników determinujących zdrowie, do których zaliczają czynniki socjo-ekonomiczne, kulturalne i środowiskowe (general socio-economic, cultural and enviromental conditions), czynniki związane z kwestiami społecznymi (social and community networks), te dotyczące stylu życia jednostek (individual lifestyle factors) i w końcu kwestie związane z płcią, wiekiem i czynnikami konstytutywnymi (age, sex and constitutional factors) (Dahlgren, Whitehead 2007: 11). Autorki publikacji Metateoretyczny kontekst zachowań zdrowotnych w paradygmatach zdrowia zauważają, że „współcześnie istnieje powszechna tendencja przejścia w stronę holistycznego

\footnotetext{
${ }^{2}$ Osoba uznana za zdrową w regionie dotkniętym wojną może nie zostać uznaną za taką w jednym z krajów "sytego" Zachodu, nie tylko ze względu na fakt doskonalszej technologii medycznej, ale także dlatego, że lekkie, niezagrażające życiu czy nieskutkujące kalectwem zaburzenie w kraju dotkniętym wojną, o wysokiej śmiertelności nie znajdzie się w „katalogu” zjawisk skutkujących utratą zdrowia.
} 
paradygmatu zdrowia" (Ślusarska, Dobrowolska, Zarzycka 2011: 667). Charles Sheridan i Sally Radmacher wskazują z kolei na ewolucję w pojmowaniu pojęcia zdrowia, za przykład biorąc homoseksualizm, problemy z nadużywaniem alkoholu czy palenie papierosów. Wskazują także na kulturowe determinanty w rozumieniu zdrowia. Wspomniani autorzy postulują pojmowanie zdrowia jako kontinuum w opozycji do rozumienia zero-jedynkowego (np. tego z definicji WHO). Z jednej strony wspomnianego kontinuum umiejscowione są osoby zagrożone przedwczesnym zgonem, a na drugim końcu osoby o optymalnym stanie zdrowia (Sheridan, Radmacher 1998: 7-11). Podobnie zdrowie rozumiane jest w strategiach i dokumentach związanych z bezpieczeństwem naszego państwa. W Strategii Bezpieczeństwa Narodowego $\mathrm{RP}^{3}$ w ramach interesów narodowych i celów strategicznych znajduje się „ochrona indywidualna i zbiorowa obywateli przed zagrożeniami dla ich życia i zdrowia oraz przed naruszeniem, utratą lub degradacją istotnych dla nich dóbr (materialnych i niematerialnych)" (b. a. 2014: 11), a także „zapewnienie trwałego i zrównoważonego rozwoju potencjału społecznego i gospodarczego państwa, ze szczególnym uwzględnieniem ochrony środowiska naturalnego oraz warunków życia i zdrowia ludności jako podstawy bytowania" (b. a. 2014: 11). W ramach wymiaru krajowego środowiska bezpieczeństwa Polski już na trzecim miejscu wymienione zostało bezpieczeństwo zdrowotne ${ }^{4}$. Bezpieczeństwo zdrowotne obywateli jest elementem koncepcji działań strategicznych, czyli tzw. strategii operacyjnej, i pozostaje częścią działań ochronnych dotyczących ochrony zdrowia w ramach zapobiegania „zagrożeniom bezpieczeństwa zdrowotnego, w tym związanych z rozwojem współczesnej cywilizacji, a także ratowanie życia i zdrowia ludności" (b. a. 2014: 38). Kwestie zdrowia wskazywane przez twórców strategii w pierwszym rzędzie mają dotyczyć zapobiegania chorób przewlekłych i cywilizacyjnych. Problematyka zdrowia w jego licznych aspektach podejmowana jest wielokrotnie w Długookresowej Strategii Rozwoju Kraju 20305. Głównym celem całokształtu działań przedstawionych w tym dokumencie jest poprawa szeroko rozumianego poziomu jakości życia obywateli Polski. Pod tym nader ogólnym celem strategii jej autorzy identyfikują szereg kwestii związanych z tzw. well being, spośród których dla celów niniejszego opracowania najistotniejsze wydają się być problemy:„długości życia w ogóle, długości życia w zdrowiu (...) poczucia satysfakcji z życia" (Polska 2030... 2013: 42, 43). Co prawda za szczególnie istotne twórcy dokumentu uważają kwestie wzrostu poziomu finansowania sektora związanego z opieką zdrowotną do $2 \%$ PKB, co można uznać niejako za "twardy" i podstawowy czynnik wzrostu poziomu zdrowia, bez którego żadne inne działania nie będą skutkowały realnymi wynikami. Jednak przy odpowiednim poziomie finansowania efekt "miękkich" czynników, związanych z promocją, edukacją m.in. rekreacyjnej aktywności fizycznej, również pozostaje

\footnotetext{
${ }^{3}$ Strategia Bezpieczeństwa Narodowego RP ma być najistotniejszym dokumentem obejmującym holistycznie kwestie związane z bezpieczeństwem państwa. O randze dokumentu może świadczyć sposób ratyfikacji Strategii, którą zatwierdza Prezydent RP na wniosek Prezesa Rady Ministrów.

${ }^{4}$ Które „współkształtuje bezpieczeństwo narodowe" (b. a. 2014: 24).

${ }^{5}$ Zgodnie z opinią Biura Bezpieczeństwa Narodowego jest ona najistotniejszym dokumentem w Polsce dotyczącym szeroko pojętych kwestii obronności (Hierarchia... 2013).
} 
niezwykle istotny. Jak podkreślono w analizowanym dokumencie, państwo ma zwrócić szczególną uwagę na "profilaktykę i promocję prozdrowotnych wzorców stylu życia” (Polska 2030... 2013: 75). W strategii wskazuje się na konieczność intensyfikacji „postępów w zwalczaniu szkodliwych dla zdrowia zachowań, takich jak używanie tytoniu, szkodliwe skutki spożywania alkoholu, niewłaściwa dieta i brak aktywności fizycznej, które prowadzą do większej zapadalności na przewlekłe choroby niezakaźne (głównie: nowotwory, choroby układu oddechowego, choroby układu krążenia, cukrzyca i choroby psychiczne)" (Polska 2030... 2013: 96). Zdaniem autorów strategii konieczne jest prowadzenie przedsięwzięć związanych z profilaktyką mających na celu promocję zdrowego stylu życia (Polska 2030... 2013: 96). Powyższe zagadnienia mają szczególną wagę, biorąc pod uwagę zarysowany kontekst dotyczący problemu starzenia się społeczeństwa i ewentualnego braku możliwości wykorzystania oczywistego potencjału osób starszych.

Również w Strategii Rozwoju Kraju 2020 (średniookresowa strategia rozwoju kraju) kwestie zdrowia, jego ochrony, profilaktyki i zachowań prozdrowotnych zajmują znaczące miejsce 6 .

Należy zwrócić uwagę, że obie strategie odnoszące się do rozwoju kraju zwracają uwagę na szkodliwość zaniedbywania aktywności fizycznej oraz działania na rzecz jej promowania i wzrostu (Polska 2030... 2013: 65).

\section{Aktywność fizyczna w wymiarze zawodowym i rekreacyjnym, analiza zjawiska na tle psychologicznym i socjologicznym}

W celu przeprowadzenia dalszych rozważań konieczna jest operacjonalizacja kolejnych pojęć kluczowych dla niniejszego opracowania. Istotna jest kwestia aktywności fizycznej, którą Barbara Woynarowska definiuje jako „wszystkie czynności i zajęcia związane z wysiłkiem fizycznym i ruchem (pracą mięśni), w czasie których czynność serca i oddech przyśpiesza, pojawia się uczucie ciepła i często pocenie się" (Woynarowska 2007: 314). Z kolei Carl J. Caspersen, Kenneth E. Powell i Gregory M. Christenson wiążą wspomnianą kwestię z wydatkowaniem energii mierzalnej w kilodżulach bądź kilokaloriach (Caspersen, Powell, Christenson 1985: 126). Do aktywności fizycznej zgodnie z powyższymi, podkreślającymi kwestie fizjologiczne definicjami możemy zaliczyć więc całą gamę działań, od sportów ekstremalnych związanych ze skrajnym wyczerpaniem organizmu zaczynając, na rekreacyjnych spacerach kończąc. Barbara Ainsworth wskazuje na szereg niezwykle różnorodnych form, takich jak jazda na rowerze, taniec,

\footnotetext{
${ }^{6}$ Podobnie jak w strategii dotyczącej działań w dłuższej perspektywie czasowej i tutaj szczególnie ważne są kwestie struktury i wielkości wydatków na zdrowie. Lecz co istotne, poświęcono też w niej część miejsca problematyce wpływu chorób na bezpieczeństwo państwa. Autorzy wskazują mianowicie na fakt, że podstawową przyczyną np. bierności zawodowej są choroby i niepełnosprawność. Spośród tych chorób najgroźniejsze są te związane z układem krążenia (których efektem było np. w 2009 roku 466,4 zgonów na 100 tys. osób, a także inne choroby cywilizacyjne pozostające w związku (zdaniem autorów) z bezpieczeństwem (Strategia rozwoju... 2012: 242, 243).
} 
bieganie, aktywności związane z wodą itp. (Ainsworth 2003: 2) Jeszcze więcej aktywności można znaleźć w Kompendium Aktywności Fizycznych, gdzie wymieniono ich kilkaset zaklasyfikowanych do kilku kategorii, wraz z przyporządkowanym wydatkiem energetycznym na każdą z nich (Ainsworth i in. 2011: 1575-1581). Autorzy publikacji Jakościowe i ilościowe aspekty aktywności fizycznej zauważają, że w „światowej literaturze pojęcie »aktywność fizyczna« używa się zamiennie z »aktywnością ruchową«" i jakkolwiek dostrzegają „subtelne różnice w semantyce tych pojęć” (Mynarski i in. 2012: 11), to na potrzeby niniejszego opracowania wystarczające będzie używanie tych pojęć zamiennie. Dookreślenia wymaga także przymiotnik „rekreacyjny”, który Mariusz Lipowski postrzega jako "dążność do doskonalenia czy środek do samourzeczywistnienia" (Lipowski 2006: 15), a tego rodzaju aktywność jest podejmowana "dla wypoczynku i odnowy sił psychofizycznych" (Lipowski 2006: 15). Warto zauważyć, że aktywność fizyczna nie musi być ustrukturalizowana, co ma miejsce w aktywności sportowej powiązanej bezpośrednio z treningiem, gdzie - jak wspomina Zbigniew Jastrzębski - najistotniejsza jest zasada kontroli, która polega na „nieustannej analizie przyczyn i wywołanych skutków" (Jastrzębski 2007: 9). Co istotne, nie ma ograniczeń wiekowych do podejmowania aktywności. Jak wspominają autorzy publikacji Aktywność fizyczna osób starszych z Wielkopolski w świetle ogólnopolskich badań PolSenior, "Osobom starszym zaleca się podejmowanie umiarkowanej aktywności fizycznej przez co najmniej 30 minut 5 dni w tygodniu" (Kantanista i in. 2013: 114).

Niezaprzeczalny pozostaje fakt wywierania znacznego wpływu kultywowania aktywności fizycznej zarówno na fizjologię, jak i na psychikę człowieka. Aktywność zdaje się skutkować pozytywnie dla wszystkich niemal sfer psychiki ludzkiej. Umiarkowana aktywność wywiera pozytywny wpływ na stan emocjonalny, pozwalając wyciszyć się, w przypadku długotrwałej aktywności, jak bieganie czy pływanie, pozwala osiągnąć stopień relaksacji podobny do medytacji. W trakcie aktywności rozładowywane są także emocje negatywne (Wojtasik i in. 2015: 366), co zdecydowanie przekłada się na dobrostan jednostki. Pozytywne emocje odgrywają także istotną rolę w przypadku startu w zawodach - branie udziału w amatorskich zawodach z grupą ludzi o podobnej pasji budzi niezwykle pozytywne stany uczuciowe. Takie stany budzi też zajęcie wysokiego, na miarę swoich możliwości, miejsca w takich zawodach, zwłaszcza w przypadku, gdy start jest niejako ukoronowaniem długiego okresu przygotowań (Sankowski 2001). Istotny jest także wpływ aktywności fizycznej na obraz własnego ciała i samooceny ${ }^{7}$, przejawiający się m.in. poprawą wyglądu związaną z regularnym treningiem (Wojtasik i in. 2015: 366), ale także z adekwatnością oceny swoich możliwości. Systematyczna aktywność fizyczna ma także wpływ na cechy osobowościowe, w tym przypadku głównie u dzieci, w przypadku których osobowość ciągle się kształtuje, podczas gdy w okresie dorosłości pozostaje już w miarę stabilną strukturą. Jak wskazuje Czechowski, aktywność fizyczna, „jest przestrzenią ludzkiego bytowania, gdzie dochodzi do

7 Jeśli weźmiemy pod uwagę osobowość niezaburzoną, a nie osoby z zakłóconym obrazem własnego ciała czy zaburzeniami kontroli, jak anorektycy czy też bulimicy, w przypadku których aktywność fizyczna może pełnić rolę podobną do kontrolowanych wymiotów. 
zespolenia świadomych czynów i zachowań (somatycznych), w których dany zawodnik, sportowiec lub ktoś świadomy podjętego ruchu spełnia się dzięki dokonywanym tu wyborom moralnym" (Czechowski 2014: 10). Kwestia aktywności fizycznej ma także wpływ na niezwykle istotny wskaźnik, tj. umiejscowienie poczucia kontroli. Zdaniem Sankowskiego możemy zdefiniować je jako "względnie trwałe przekonanie o tym, od czego zależą wyniki naszego działania"(Sankowski 2001). Jeśli człowiek ma przeświadczenie, że całokształt jego działań ma wpływ na jego życie, mówi się o poczuciu kontroli wewnętrznej, jeśli natomiast jest przekonany, że jego życie zależy od sił niezależnych od niego (jak np. siły natury, bogowie), mówi się o zewnętrznym poczuciu kontroli ${ }^{8}$. Jak wskazuje Sankowski, zgodnie z szeregiem badań aktywność fizyczna wywiera wpływ na kształtowanie wewnętrznego poczucia kontroli (Sankowski 2001), co zdecydowanie należy uznać za efekt pozytywny.

Ostatnim z analizowanych czynników w wymiarze psychologicznym jest kwestia poczucia jakości życia. Jak twierdzą Małgorzata Walczak i Maciej Tomczak, jakość życia może być zdefiniowana jako „wypadkowa ustosunkowania się jednostki do własnego samopoczucia psychicznego i fizycznego, bytu materialnego, posiadanych stosunków interpersonalnych, możliwości rozwoju osobistego i poczucia podmiotowości" (Walczak, Tomczak 2011:219, 220). Autorzy ci na drodze szeregu analiz (po przeprowadzeniu ankiet na grupie 190 osób) stwierdzili istotny związek pomiędzy motywacją do aktywności fizycznej i „stopniem zaspokojenia potrzeb psychologicznych a ogólnym poczuciem jakości i radości życia ogółu badanych“" (Walczak, Tomczak 2011:219, 220).

Kolejną perspektywą aktywności fizycznej, którą należy nakreślić, jest spojrzenie z punktu widzenia socjologii. Podobnie jak w przypadku kwestii psychologicznych jest to szeroka sfera, w związku z czym poruszono jedynie kilka najistotniejszych zagadnień z tego zakresu.

Interesująca z punktu widzenia socjologii, traktującej człowieka głównie jako istotę funkcjonującą w społeczeństwie, a jednocześnie istotę je tworzącą, jest sama geneza podejmowania aktywności fizycznej. Zdaniem Arkadiusza Kołodzieja „aktywność taką podejmuje się zatem często dla uzyskania, względnie utrzymania, kulturowo narzuconego wyglądu, który w dużej mierze można utożsamić z sylwetką wysportowaną" (Kołodziej 2015: 7). Wskazać można także na sport jako pewną metodę kreacji siebie wobec innych; ma to szczególne znaczenie i daje szczególne możliwości w dobie mediów społecznościowych ${ }^{9}$. Każdy kto zdobędzie nagrodę za udział w zawodach może także zaprezentować ją znajomym, co jak zauważa Kołodziej „definiuje

\footnotetext{
${ }_{8}$ Przy czym istotna jest adekwatność poczucia kontroli związana z prawidłowym postrzeganiem rzeczywistości. Za patologiczną należy uznać sytuację, gdy człowiek w normalnych warunkach nie podejmuje określonych działań, ponieważ jest przekonany, że nie mają sensu, gdyż zrealizować je może np. Bóg, z drugiej strony możliwa jest sytuacja mająca miejsce np. w trakcie wojny, gdzie człowiek o zaburzonej osobowości może posiadać fałszywe poczucie kontroli.

${ }_{9}$ Niejednokrotnie na portalach, takich jak Facebook, zauważa się informacje dotyczące ukończenia przez kogoś zawodów biegowych, spływu kajakowego czy zamieszczenie zdjęć ilustrujących pobyt na stoku narciarskim.
} 
go, odróżnia od innych nie-biegaczy i tworzy więź (wspólną kategorię) z innymi biegaczami" (Kołodziej 2015: 7). Wspomniana wspólnota z innymi biegaczami ma znamiona pewnego szczególnego związku, który objawia się np. życzliwością okazywaną innym przed, po czy w trakcie zawodów. Z drugiej strony w społeczeństwie wciąż funkcjonuje wizja „samotnego długodystansowca”(Stempień 2016: 103). Przynajmniej niektóre badania zdają się potwierdzać tą tezę, zgodnie z wynikami ankiet przeprowadzonych przez Jakuba Stempnia $68 \%$ osób zawsze bądź na ogół biega samotnie, jednak - jak dalej zauważa - uczestnicy badania często podejmowali z innymi biegaczami aktywności związane z bieganiem, jak choćby rozmowy (Stempień 2016: 103). Podobne grupy tworzą się w przypadku innych aktywności fizycznych, jak joga, cross training czy turystyka rowerowa. Wskazuje to, pomimo pewnych wciąż istniejących w społeczeństwie „klisz”, na zdecydowanie socjalizacyjną wartość aktywności i funkcjonowanie osób uprawiających aktywność fizyczną w grupach.

\section{Aktywność a zdrowie fizyczne i psychiczne człowieka}

W świetle współczesnych badań i literatury jasne stało się, że aktywność fizyczna nie pozostaje bez wpływu na zdrowie człowieka. W znacznej większości przypadków aktywność ta wywiera pozytywny wpływ na dobrostan jednostki. Jak podnosi Zofia Żukowska, ,aktywność fizyczna stanowi kluczowy i integrujący składnik zdrowego stylu życia. Bez niej niemożliwa jest jakakolwiek strategia zdrowia, jego utrzymanie i pomnażanie" (Żukowska 2008: 10). Jak wspomina Józef Drabik, w eksperymentach polegających na przymusowej deprywacji ruchu efektem u badanych były halucynacje czy zaburzenia poznawcze (Drabik i in. 2010: 35). Oczywiście nie każdy ma taki sam potencjał do kultywowania aktywności, a genotyp oraz fenotyp człowieka wywiera wpływ na jego możliwości treningu, dodatkowo sam trening wpływa na warunki fizyczne (Wojtasik i in. 2015: 356), jednak powyższe, w większości przypadków, nie ma dużego przełożenia na amatorskie formy aktywności.

Analizy wymaga jednak wpływ, jaki wysiłek fizyczny wywiera na układy narządów człowieka. Dzięki aktywności fizycznej u dzieci tkanka kostna przyrasta szybciej i jest bardziej stabilna oraz odporna (Wojtasik i in. 2015: 358). Regularny ruch ma także pozytywny wpływ na cały układ kostno-stawowy, zwiększając ruchomość jego elementów (nie tylko u dzieci) (Knapik i in. 2005: 6). Rekreacyjna aktywność nie pozostaje także bez wpływu na układ mięśniowy. Zależnie od uprawianych form aktywności, które skutkują wysiłkiem długotrwałym (powyżej godziny, np. biegi długodystansowe), wysiłkiem o średnim czasie trwania (od kilkunastu do kilkudziesięciu minut) lub wysiłkiem krótkotrwałym (kilkadziesiąt sekund, np. biegi sprinterskie) (Wojtasik i in. 2015: 354) oraz rodzajami przemian w mięśniach, które dzielą się na tlenowe lub beztlenowe, można zaobserwować wiele różnych zmian zachodzących w mięśniach (w których znajduje się szereg różnych włókien, np. wolnokurczące i szybkokurczące, które to dzielą się na kolejne grupy) (Celichowski 2014: 105). Zależnie od rodzaju uprawianej aktywności 
może dochodzić do zwiększania masy mięśni, poprawy siły skurczu, zwiększenia poprawy odporności na zwiększenie wysiłku (Celichowski 2014: 105, 106), a także wzrostu „liczby naczyń włosowatych w mięśniach"(Wojtasik i in. 2015: 356).

Kolejnym układem, na który wyraźny wpływ ma aktywność fizyczna, jest układ krążenia - skomplikowany system składający się z trzech zasadniczych elementów, tj. serca, naczyń krwionośnych i krwi. Wysiłek fizyczny wpływa praktycznie na każdy z tych elementów. Podstawowym efektem regularnych treningów jest „zwolnienie spoczynkowej wartości skurczów serca - czyli zwolnienie tętna”10. Efektem jest także „zmniejszenie pracy mięśnia sercowego i jego zapotrzebowania na tlen (...) zwiększenie zdolności relaksacyjnej tętnic oraz zwiększenie liczby naczyń włosowatych w trenowanych mięśniach"(Nazar 2001: 235). Wszystko to przekłada się bezpośrednio na dobrostan człowieka, co wykazano np. w badaniu opisanym w publikacji Physical activity and cardiovascular risk factors among elderly men in Finland, Italy and The Netherlands (Bijnen i in. 1996: 553-561). Także układ nerwowy dzięki kultywowaniu aktywności fizycznej podlega nader pozytywnym zmianom, należą do nich np. „zwiększenie siły, polepszenie precyzji oraz płynności ruchów"(Celichowski, Krutki 2001: 100), a także ogólna ochrona centralnego układu nerwowego (Wojtasik i in. 2015: 362).

Reasumując, aktywność fizyczna ma dobroczynny wpływ na wszystkie układy organizmu człowieka oraz na organizm jako całość w sensie strukturalnym i funkcjonalnym. Przede wszystkim efektem aktywności są zjawiska prowadzące do adaptacji poszczególnych układów. Kości osób trenujących są znacznie lepiej uwapnione i mają większą gęstość, a stawy są znacznie bardziej elastyczne, przez co są znacznie bardziej odporne na urazy (Wojtasik i in. 2015: 366). Aktywność zapobiega także wadom postawy i koryguje te, do których już doszło (Biernat 2014: 1). Dzięki oddziaływaniu na układ nerwowy uprawianie sportu poprawia samopoczucie i polepsza jakość snu (Biernat 2014: 2). Poprawa samopoczucia wiąże się zapewne m.in. z pobudzonym wydzielaniem endorfin (Ostrowska 1999: 80). Nie bez znaczenia aktywność fizyczna pozostaje dla regulacji przemiany materii - według badań stale wzrasta średnia wartość kaloryczna posiłków we współczesnych społeczeństwach z kręgu kultury Zachodu (Marchewka, Jungiewicz 2008: 127). Jak twierdzą Krystyna Nazar i Hanna Kaciuba-Uściłko, „aktywność ruchowa wywiera również bezpośredni wpływ na przemianę materii, co ułatwia utrzymanie równowagi między ilością energii dostarczanej z pożywieniem i wydatkowanej przez organizm i przyczynia się do właściwej dystrybucji składników spożywanego pokarmu" (Nazar, Kaciuba-Uściłko 2001: 532), a w przypadku osób przewlekle chorych często prowadzi do poprawienia równowagi kwasowo-zasadowej (Duda 2001: 405). Zgodnie z badaniami aktywność fizyczna jest także istotnym czynnikiem np. w niższym ryzyku śmierci spowodowanej zaburzeniami cukrzycowymi, co udowadniają autorzy opracowania Fitness, fatness and survival in adults with prediabetes (McAuley i in. 2014: 529-536). Center for Disease Control and Prevention publikuje

${ }^{10}$ Które zwykle wynosi 70, a u osób uprawiających spada do 50 lub mniej uderzeń na minutę (Posłuszny, Lapina 2011: 24). 
informacje, zgodnie z którymi aktywność ruchowa może zapobiec 1 na 8 przypadków raka piersi, 1 na 8 przypadków raka jelita grubego, 1 na 12 przypadków cukrzycy czy 1 na 15 przypadków chorób serca (National Center for Chronic Disease Prevention and Health Promotion 2019). Zgodnie z analizami Departamentu Zdrowia Stanów Zjednoczonych (U.S. Department of Health \& Human Services) oprócz zapobieganiu chorobom aktywność fizyczna powoduje cały szereg korzystnych dla zdrowia zmian, jak np. redukcja tłuszczu i kontrola wagi, poprawa snu, unikanie stresu (President's Council on Sports, Fitness \& Nutrition 2017). Także Unia Europejska, dostrzegając znaczenie aktywności fizycznej, w raportach i analizach wskazuje na korzyści z aktywności fizycznej, ponadto wskazywany jest fakt, że ciało ludzkie jest stworzone do tego, by się poruszać i potrzebuje ruchu do prawidłowego rozwoju (Andersen i in. 2008: 3). Ponadto zgodnie z dokumentami Unii Europejskiej „aktywność fizyczna jest wstępnym warunkiem zdrowego stylu życia" (Baraskausas 2013: 2). W literaturze istnieje szereg badań potwierdzających pozytywny wpływ aktywności fizycznej na zdrowie, niezależnie od wieku. Zależność tę potwierdzają np. autorzy publikacji Aktywność fizyczna a zdrowie kobiet $w$ wieku starszym, którzy wskazują na korelację pozytywną pomiędzy aktywnością fizyczną a zdrowiem (w samoocenie badanych) (Knapik i in. 2011: 27). Teresa Makowiec-Dąbrowiecka, prezentując wyniki badań przeprowadzonych m.in. w Finlandii, zasadniczo udowadnia pozytywny wpływ aktywności, „umieralność ze wszystkich przyczyn i z powodu chorób układu krążenia była mniejsza wśród tych, którzy deklarowali umiarkowaną lub dużą aktywność w czasie wolnym niż wśród tych, którzy prowadzili siedzący tryb życia" (Makowiec-Dąbrowska 2012: 132). Jednak autorka przytacza także szereg innych badań, w których rozważano m.in. aktywność fizyczną o znacznym natężeniu, efekty których dla zdrowia mogą być negatywne (Makowiec-Dąbrowska 2012: 133-137).

Warto bowiem zauważyć, że aktywność fizyczna niesie ze sobą także szereg zagrożeń, o których nie można zapominać. Podzielić możemy je na takie, które pozostają niezależne od uprawianej aktywności. Można bowiem założyć, że większą szansę na drobne urazy ortopedyczne czy inne drobne zaburzenia ma osoba aktywna od tej spędzającej większość wolnego czasu przed telewizorem, jednak przyjąć należy, że wymienione uprzednio pozytywne efekty aktywności fizycznej przeważają nad ewentualnymi urazami (mowa tu o aktywności dobranej adekwatnie do możliwości). Szereg zagrożeń wiąże się bowiem z nieodpowiednio dobranymi obciążeniami treningowymi, przy czym różni autorzy przedstawiają odpowiednie zalecenia co do intensywności treningu. Skarżyński mówi o objętości biegowej około 40 kilometrów tygodniowo (Skarżyński 2015: 80), Nazar i Kaciuba-Uściłko wspominają o tym, że bezpieczna ilość sesji treningowych to minimum dwie, a maksymalnie cztery tygodniowo trwające po 30-40 minut o umiarkowanej intensywności bez nadmiernego obciążania układów ruchu. Przy czym każdy trening powinien zostać poprzedzony rozgrzewką, a zakończony aktywnością relaksacyjną (Nazar, Kaciuba-Uściłko 2001:541, 542). Amerykańscy badacze wspominają z kolei o znacznym wpływie dla zdrowia umiarkowanej aktywności na poziomie 150-300 minut tygodniowo (Powell, Paluch, Blair 2011: 
350). Zgodnie z raportem przygotowanym przez American College of Sports Medicine i American Heart Association korzystne jest łączenie aktywności o różnej intensywności (np. spacer i jogging) oraz różnych ćwiczeń (np. siłowych z joggingiem) (Haskell i in. 2007: 1-13). Mariusz Lipowski wskazuje na możliwe „zwyrodnienia” aktywności, takie jak maraton czy triatlon (Lipowski 2006: 15), ale z kolei Scott Jurek, utytułowany ultramartończyk, uważa, że „pod pewnym względem ultramaraton jest łatwiejszy niż zwykły maraton. Podczas krótszego, szybszego biegu miałbym wyższe tętno, a moje płuca byłyby bardziej obciążone" (Jurek 2012: 214). Nieadekwatny dobór obciążenia niesie ze sobą szereg zagrożeńn ${ }^{11}$. Najbardziej skrajnym przypadkiem niedostosowania obciążenia treningowego (startowego) do możliwości uprawiającego jest śmierć związana z aktywnością. Kolejną "mroczną" stroną aktywności fizycznej przejawiającą się u niektórych jest uzależnienie od niej ${ }^{12}$. Efektem tego rodzaju uzależnienia może być przeprowadzanie jednostek treningowych pomimo przeciążenia, zbyt krótki czas regeneracji, uczynienie z treningu centrum swojego życia, lekceważenie przy tym obowiązków rodzinnych czy zawodowych, reagowanie na niepowodzenia życiowe podejmowaniem treningu zamiast racjonalnych działań oraz kompulsywne działania mające regulować negatywne stany emocjonalne. Wszystkie te zjawiska i wiele innych wskazują na możliwe uzależnienie. Problem ten najczęściej dotyka osoby uprawiające aktywność fizyczną na wysokim poziomie amatorskim, albo też osoby te trenują na takim poziomie ze względu na uzależnienie. Do osób, które trenowały na wysokim poziomie, a jednocześnie nie przeszły na poziom w pełni zawodowy ${ }^{13}$, należy z całą pewnością utytułowana biegaczka Magdalena Dołęgowska, która na swoim blogu wspomina o kompulsywnych potrzebach związanych z aktywnością (Ostrowska-Dołęgowska 2017). W potocznej opinii uzależnienie od teoretycznie prozdrowotnych zachowań jest mniej szkodliwe od alkoholizmu czy narkomanii, jednak biorąc pod uwagę identyczny mechanizm - może być równie wyniszczające.

\section{Wpływ rekreacyjnej aktywności fizycznej na podsystemy bezpieczeństwa społecznego i gospodarczego państwa}

Z analizy zaprezentowanej dotychczas jednoznacznie wynika olbrzymi wpływ, jaki uprawianie rekreacyjnej aktywności ruchowej wywiera na zdrowie. Przedmiotem tej części opracowania jest kwestia wpływu zdrowia na kwestie społeczne i gospodarcze

\footnotetext{
${ }^{11}$ Do najlżejszych należy przetrenowanie; zgodnie z literaturą powodowane jest ono zbyt dużymi obciążeniami oraz zaburzeniem równowagi i odpowiednich stosunków pomiędzy treningiem, a regeneracją. Skutkiem przetrenowania może być szereg dolegliwości psychicznych i fizycznych, tj. obniżone samopoczucie, trudności w zasypianiu i przebiegu snu, niechęć do treningu, spadek masy mięśniowej, ogólne dolegliwości bólowe itp. (Kochański i in. 2015: 51).

${ }_{12}$ Anna Dodziuk i Leszek Kapler definiują, że „zachowanie można uznać za nałogowe, jeżeli je powtarzam, chociaż wiem, że przynosi szkody mnie lub innym. Nawyk, który przeszkadza, ogranicza, niszczy, a jednak nie sposób się z nim rozstać; przyzwyczajenie, które mimo postanowień o zaprzestaniu nie daje się zmniejszyć, ani wykorzenić, jest niczym innym niż nałogiem" (Kapler, Dodziuk 2007: 19).

${ }^{13}$ Nie ze względu na brak umiejętności, a raczej fakt, że w biegach ultradługich w Polsce nie ma wystarczającej ilości środków finansowych, by mogli funkcjonować zawodowi zawodnicy.
} 
państwa, które, jak wskazano uprzednio, są, zgodnie z dokumentami dotyczącymi bezpieczeństwa w Polsce, jednymi z kluczowych elementów bezpieczeństwa narodowego.

Jak można zdefiniować bezpieczeństwo społeczne? Według Dariusza Lorantego jest to "stan struktury i kultury społeczeństwa oraz systemu podziału pracy, umożliwiający obywatelom osiąganie wartości indywidualnych, a także utrzymanie i umacnianie więzi społecznej zapewniającej kształtowanie wspólnotowej tożsamości, a także stan przejawiający się w podejmowaniu działań na rzecz dobra wspólnego" (Loranty 2007: 200-201). Nieco inną perspektywę zarysowuje Marek Leszczyński, zdaniem którego „bezpieczeństwo społeczne obejmuje całokształt działań prawnych, organizacyjnych realizowanych przez podmioty rządowe (krajowe i międzynarodowe), pozarządowe i samych obywateli, które mają na celu zapewnienie pewnego poziomu życia osobom, rodzinom i grupom społecznym oraz niedopuszczenie do ich marginalizacji i wykluczenia społecznego"(Leszczyński 2011: 125). W powyższej definicji widoczne jest przesunięcie ciężaru odpowiedzialności za bezpieczeństwo społeczne w kierunku podmiotów państwowych - chociaż nie wyłącznie. Bezpieczeństwo gospodarcze w literaturze przedmiotu jest z kolei używane zamiennie z określeniem bezpieczeństwo ekonomiczne. Zdaniem badaczy pojęcie to dotyczy „, wielkości potencjału ekonomicznego oraz stanu świadomości obywateli oraz przedstawicieli organów państwa, który pozwala samodzielnie, według jasnych procedur, decydować o kierunku, celach i dynamice rozwoju gospodarczego oraz skutecznie rozpoznawać zagrożenia i zapobiegać czynnikom zewnętrznym i wewnętrznym, które ten proces rozwoju mogłyby bądź usiłują zakłócić" (Ciekanowski, Nowicka, Wyrębek 2016: 54). Zarysowane zostały tu trudniej mierzalne niż czynniki stricte ekonomiczne kwestie świadomości obywateli, które z pewnością nie są kluczowe, jednak należy podkreślić ich niewątpliwy wpływ na poziom tego wymiaru bezpieczeństwa. Kwestie wspomnianych „twardych" czynników gospodarczych są określane m.in. w National Security Index, który ma być wskaźnikiem potęgi państw ${ }^{14}$.

Pierwszym sposobem wpływu wywieranego przez aktywność fizyczną, głównie za pośrednictwem poprawy stanu zdrowia, na powyższe aspekty bezpieczeństwa jest oddziaływanie poprzez wzrost wydajności pracy. Na podstawie analiz można stwierdzić, że pracownik w lepszej kondycji fizycznej i psychicznej pracuje znacznie wydajniej. Kwestia ta jest dostrzegana przez środowiska naukowe zajmujące się zarządzaniem zasobami ludzkimi. Jak przytacza Marzena Malińska, zgodnie z badaniami przeprowadzonymi przez Canadian Fitness and Lifestyle Research Institute efektem aktywności fizycznej w ujęciu rekreacyjnym jest m.in. „zmniejszenie kosztów opieki zdrowotnej, absencji chorobowej, liczby wypadków i rotacji pracowników oraz wzrost produkcji

\footnotetext{
14 Jak piszą Marian Brzeziński i Szymon Mitkow, wg wersji indeksu z 2012 roku aż 25\% zmiennych dotyczących potęgi państwa związanych jest z możliwościami gospodarczymi. Podczas gdy w zakres indeksu dotyczącego kwestii gospodarczych wchodzi Produkt Krajowy Brutto w 60\% określający siłę danego państwa, w 35\% potęga gospodarcza związana jest z obrotami w handlu zewnętrznym, a 5\% składnika pochodzi ze średniej stopy wzrostu PKB w ostatnich pięciu latach (Brzeziński, Mitkow 2014: 488).
} 
firmy, ale także poprawa stanu zdrowia i samopoczucia pracowników, relacji między współpracownikami oraz satysfakcji zatrudnionych z pracy i kultury organizacyjnej (Malińska 2017: 277). Zgodnie z informacjami udostępnianymi przez Centralny Instytut Ochrony Pracy aktywność fizyczna powinna być elementem zrównoważonego trybu życia i pracy (work life balance), którego stosowanie zdecydowanie poprawia efektywność pracy. Wystarczy podkreślić, że zgodnie z badaniami zdrowi pracownicy pracują efektywniej i lepiej wykorzystują narzędzia pracy, szczególnie te związane z technologią (Hermanowski, Drozdowska 2013: 19). Ważny jest także wpływ zdrowia na kwestie związane z nieobecnością w pracy, osoby o kiepskim stanie zdrowia wykazują większą absencję w pracy, co naraża na koszty nie tylko pracodawcę, ale cały system ubezpieczeń społecznych, ponieważ przy dłuższej nieobecności to właśnie Zakład Ubezpieczeń Społecznych wypłaca zasiłek chorobowy. Wpływ na system mają także choroby, leczenie których w przypadku Polski obciąża samych obywateli ${ }^{15}$. Jak podnosi Jakub Gierczyński, ,najważniejszymi przyczynami obciążenia chorobowego, w przeliczeniu na utracone potencjalne lata życia z uwzględnieniem niesprawności, są choroby przewlekłe niezakaźne (76,7\% wszystkich zachorowań)"(Gierczyński 2012: 95), czyli głównie choroby cywilizacyjne, których występowaniu zapobiegać może aktywność fizyczna ${ }^{16}$. Według publikacji z 2012 roku społeczeństwo UE wydawało 798 mld euro rocznie na leczenie chorób neuropsychiatrycznych, $192 \mathrm{mld}$ na leczenie chorób sercowo-naczyniowych, $125 \mathrm{mld}$ na leczenie otyłości, a $40 \mathrm{mld}$ na leczenie cukrzycy (Gierczyński 2012: 95).

Analizę związku wydatków na aktywność z ewentualnymi oszczędnościami Polski poruszają autorzy raportu analitycznego Ocena korzyści społecznych inwestycji w sport wodniesieniu do ponoszonych kosztów, który powstał w 2016 roku na zlecenie Ministerstwa Sportu i Turystyki. Wskazuje się w nim, że w 2012 roku jedynie $41 \%$ gospodarstw w Polsce poniosło wydatki na aktywność sportowo-rekreacyjną, a średnie wydatki, biorąc pod uwagę wszystkie gospodarstwa, wyniosły 418 zł na jedno, podczas gdy całkowite wydatki państwa na sport trzy lata później wyniosły 4,6 mld zł. W raporcie poddano też analizie poziom aktywności obywateli Polski - we wnioskach podkreślono, że jedynie $39 \%$ z nich jest aktywnych w stopniu zalecanym przez WHO.

Bardzo interesujące są prognozy związane z ewentualnym wzrostem liczby osób aktywnych w Polsce. Autorzy analizują w związku z tym trzy scenariusze; zgodnie z pierwszym z nich aktywnych jest o $10 \%$ osób więcej, zgodnie z kolejnym $50 \%$ osób, które nie robiły tego do tej pory, zgodnie z trzecią wersją symulacji wszyscy dotychczas nieaktywni zaczynają uprawiać aktywność ruchową. Już w przypadku pierwszego scenariusza korzyści są znaczne, są nimi m.in. spadek współczynnika umieralności (o 1,35\%), poprawa wskaźników zatrudnienia, zmniejszenie absencji w pracy o (2\%)

${ }^{15}$ Czy za pośrednictwem Narodowego Funduszu Zdrowia finansowanego z ubezpieczeń czy budżetu państwa w przypadku niektórych świadczeń.

${ }^{16}$ Choroby generują trzy rodzaje kosztów: bezpośrednie, do których należą środki wydatkowane bezpośrednio na leczenie, bezpośrednie, do których należą straty związane z obniżeniem jakości pracy, oraz koszty niepoliczalne, czyli np. cierpienie chorego (patrz Gierczyński 2012: 96). 
(Baran, Lis, Magda 2016: 35), które w samym 2017 roku przynosi oszczędności w wysokości $1 \mathrm{mld}$ zł, zmniejszenie o 17 tys. liczby otyłych obywateli, a o 54 tys. tych z nadwagą. Biorąc pod uwagę założenie bazowe, spada także liczba osób cierpiących na niektóre schorzenia, takie jak nowotwory, cukrzyca czy choroby układu krążenia - co przynosi dla systemu opieki zdrowotnej oszczędności w wysokości $120 \mathrm{mln}$ zł. Gdyby udało się doprowadzić do zaktywizowania połowy nieaktywnych do tej pory osób, liczba nieobecności w pracy spadłaby o 6\%, co daje oszczędności w wysokości 3 mld zł rocznie. Osób otyłych jest mniej o 64 tys., a tych z nadwagą o 190 tys., co w połączeniu ze spadkiem liczby chorych przynosi oszczędności w wysokości $440 \mathrm{mln}$ rocznie. W trzecim z analizowanych przypadków oszczędności w wyniku zmniejszonej absencji pracowników wynoszą 6 mld zł, a oszczędności służby zdrowia 900 mln zł (Baran, Lis, Magda 2016: 10-46). Ostatnia z prognoz jest co prawda całkowicie nierealna, jednak uwidacznia całościowe koszty, jakie ponosi Polska w związku z brakiem aktywności fizycznej. Jednak kwestia poprawiającego się zdrowia obywateli, które skutkuje przedłużeniem długości ich życia, może zdaniem niektórych badaczy zwiększyć koszty opieki zdrowotnej. Miałoby się tak dziać ze względu na to, że dłużej żyjący, starsi ludzie chorują na znaczną ilość chorób przez dłuższy czas, co generuje wyższe koszty niż śmierć w młodszym wieku. Hermanowski i Drozdowska przytaczają szereg badań potwierdzających, jak i sprzecznych z tą tezą - zgodnie z ich opinią aktualnie nie ma możliwości potwierdzenia bądź obalenia tego kontrowersyjnego założenia (Baran, Lis, Magda 2016: 20-28). Jak wynika z powyższych wyników badań, regularne uprawianie rekreacyjnej aktywności fizycznej, poprzez poprawę stanu zdrowia w niektórych jego aspektach, wywiera niewątpliwy wpływ na podsystemy bezpieczeństwa społecznego i gospodarczego.

\section{Zakończenie}

W toku realizacji badań przeprowadzono analizę szeregu założonych problemów. Udało się wykazać powiązanie regularnego kultywowania aktywności fizycznej z rozwojem pozytywnym jednostki w aspekcie psychicznym, socjalnym i fizycznym oraz, co istotne, ze zwiększonym poczuciem jakości własnego życia. Aczkolwiek zarysowano pojawiającą się w niektórych przypadkach tendencję odwrotną, która ma związek z nadużywaniem tego rodzaju aktywności, co często wiąże się z uzależnieniem od rekreacji ruchowej, jest to problem, który zdaniem autora nie jest wystarczająco dyskutowany, a z całą pewnością ma wpływ na bezpieczeństwo indywidualne, a przez to także na szerszy wymiar. Na podstawie stosunkowo wyczerpujących analiz wskazano na umiejscowienie kwestii zdrowia obywateli w dokumentach strategicznych dotyczących bezpieczeństwa i rozwoju funkcjonujących w Polsce w ciągu ostatnich kilkunastu lat, a także w strategiach brytyjskich.

Zwrócono także uwagę na kwestie chorób cywilizacyjnych będących szczególnie istotnym problemem dla bezpieczeństwa państw Unii Europejskiej, na zapobieganie 
i niwelowanie ich skutków, i szczególny wpływ aktywności ruchowej. Zgodnie z badaniami Ocena korzyści społecznych inwestycji w sport w odniesieniu do ponoszonych kosztów (Baran, Lis, Magda 2016: 10-46) nawet niewielki wzrost tendencji do bycia aktywnym w zalecany, bezpieczny sposób doprowadzić może w Polsce do znacznych oszczędności (rzędu ponad miliarda złotych w stosunku rocznym). Co jednak warto zaznaczyć, w trakcie prowadzonych badań udało się dotrzeć do opracowań wskazujących też na nieco inny mechanizm. Mianowicie zgodnie z wynikami niektórych badań całkowite koszty związane z polepszaniem jakości zdrowia mogą przekroczyć wynikające z tego faktu korzyści, co związane jest z dużymi kosztami ponoszonymi na specjalistyczną opiekę nad osobami starszymi. W uproszczeniu według tej opinii szybsza śmierć osób chorych odciąża państwo od długotrwałej niezwykle kosztochłonnej pielęgnacji osób starszych, co ma przynosić oszczędności. Powyższe twierdzenie, jakkolwiek cyniczne, wymaga zapewne sprawdzenia i oceny zastosowanej w toku badań metodologii, a także tego, jakie koszty zostały wzięte pod uwagę (np. trudniej szacowalne koszty związane z bezpieczeństwem społecznym czy kapitałem ludzkim osób starszych, które przecież również w wieku emerytalnym generują zyski dla państwa, zwiększając w ten sposób jego bezpieczeństwo). Ze względu na charakter pracy skoncentrowano się na innych problemach, jednak temat ten z pewnością zasługuje na dalsze badanie, podobnie jak potrzebna jest głębsza refleksja nad zorganizowanymi programami państwa, których celem jest wsparcie kwestii zdrowotnych. Szczególnie chodzi o kwestię implementacji Narodowego Programu Zdrowia, w ramach którego propagowana jest także aktywność fizyczna. W toku pracy (pomimo pewnych wymagających doprecyzowania wątpliwości) udało się potwierdzić postawioną hipotezę, jak i uzyskać odpowiedzi na pomocnicze pytania badawcze, pojawiło się jednocześnie wiele innych tematów powiązanych z już badanymi, które z całą pewnością warte są szerszego opracowania w przyszłości.

\section{Bibliografia}

Ainsworth B. i in., 2011, Compendium of physical activities: a second update of codes and MET values, "Medicine \& Science in Sports \&Exercise", No. 43(8).

Ambroży T., Mucha D., Nowak M., Ambroży D., Mucha T., 2015, Fizjologia treningu siłowego jako forma profilaktyki zdrowotnej i przeciwdziałania zagrożeniom cywilizacyjnym, „Kultura. Bezpieczeństwa. Nauka - Praktyka - Refleksje", nr 17.

Andersen L.B. i in., 2008, EU Physical Activity Guidelines. Recommended policy actions in suport of health-enhancing physical activity.

Antonovsky A., 1995, Rozwikłanie tajemnicy zdrowia. Jak radzić sobie ze stresem i nie zachorować, Warszawa.

Baran J., Lis M., Magda I., 2016, Ocena korzyści społecznych inwestycji w sport w odniesieniu do ponoszonych kosztów, Warszawa.

Baraskausas D.A., 2013, Council Recommendation on promoting health-enhancing physical activity across sectors, Bruksela. 
Bąk-Romaniszyn L. (red.), 2013, Choroby społeczne i cywilizacyjne - wybrane zagadnienia, Łódź. Biernat E., 2014, Aktywność fizyczna w życiu współczesnego człowieka, „e-wydawnictwo NCBKF”, Warszawa.

Brzeziński M., Mitkow S., 2014, Metody oceny systemu bezpieczeństwa narodowego „,Logistyka”, nr 6. Caspersen C.J., Powell K.E., Christenson G.M., 1985, Physical activity, exercise and physical fitness: definitions and distinctions for health-related research, „Public Health Report", No. 100.

Celichowski J., 2014, Budowa i czynność tkanki mięśniowej [w:] J. Górski (red.), Fizjologiczne podstawy wysiłku fizycznego, Warszawa.

Celichowski J., Krutki P., 2014, Czynność układu nerwowego w procesie treningu, [w:] J. Górski (red.), Fizjologiczne podstawy wysiłku fizycznego, Warszawa.

Chojnowski L., 2016, Bezpieczeństwo narodowe. Studium teoretyczne, Słupsk.

Ciekanowski Z., 2010, Rodzaje i źródła zagrożeń bezpieczeństwa, „Bezpieczeństwo i Technika Pożarnicza", nr 17 (1).

Ciekanowski Z., Nowicka J., Wyrębek H., 2016, Bezpieczeństwo państwa w obliczu współczesnych zagrożeń, Siedlce.

Ciszek M., 2014, Determinanty ekonomiczne kształtujące bezpieczeństwo wewnętrzne I trwałość państwa. Systemowa filozofia postrzegania gospodarczych podstaw bezpieczeństwa RP ,„Edukacja dla Bezpieczeństwa", t. VII, $\mathrm{nr} 3$ (24).

Czachór Z., 2014, Bezpieczeństwo państwa w Unii Europejskiej na przykładzie Polski. Analiza realistyczna i państwowo-centryczna, "Przegląd Strategiczny”, nr 7.

Czechowski J., 2014, Sport szansą społecznego rozwoju człowieka,,'Społeczeństwo i Ekonomia”, nr 1(1). Czuryk M., Dunaj K., Karpiuk M., Prokop K., 2016, Bezpieczeństwo państwa zagadnienia prawne i administracyjne, Olsztyn.

Dahlgren G., Whitehead M., 2007, Policies and strategies to promote social equity in health, Sztokholm. Domaradzki J., 2013, O definicjach zdrowia i choroby , „Folia Medica Lodziensia”, nr 40/1.

Domaradzki J., 2013, O skrytości zdrowia. O problemach z konceptualizacja pojęcia zdrowie, „Hygeia Public Health", No. 48 (4);

Drabik J., Pańczyk W., Resiak M., Łysak A., Walentukiewicz A., Wilk B., Włodarczyk P., Zaleska A., Ziółkowski A., 2010, Promocja zdrowia i zachowań zdrowotnych [w:] J. Drabik, M. Resiak (red.), Styl życia w promocji zdrowia, Gdańsk.

Duda K., 2001, Równowaga kwasowo-zasadowa [w:] J. Górski (red.), Fizjologiczne podstawy wysiłku fizycznego, Warszawa.

Gierczyński J., 2012, Wpływ kosztów chorób cywilizacyjnych na politykę zdrowotną w krajach Unii Europejskiej i w Polsce ,",Polityka Zdrowotna”, t. X, marzec.

Gierszewski J., 2013, Model bezpieczeństwa społecznego na tle teorii systemów „,'Colloquium Wydziału Nauk Humanistycznych i Społecznych AMW kwartalnik", nr 2.

Haskell W.L., Min Lee I., Pate R.R., Powell K.E., Blair S.N., Franklin B.A., Macera C.A., Heath G.W., Thompson P.D., Bauman A., 2007, Physical Activity and public health. Updated recommendation for adults from The American College of Sports Medicine and The American Heart Association, "Circulation - Journal of The American Heart Association", August 28.

Hermanowski T., Drozdowska A., 2013, Ocena wartości życia i zdrowia, pomiar korzyści zwiqzanych z technologiami medycznymi, rodzaje kosztów w opiece zdrowotnej [w:] T. Hermanowski (red.), Szacowanie kosztów społecznych choroby i wpływu stanu zdrowia na aktywność zawodowq i wydajność pracy, Warszawa. 
Heszen I., Sęk H., 2007, Psychologia zdrowia, Warszawa.

Hildt-Ciupińska K., Równowaga praca - życie. Materiały informacyjne, https://m.ciop.pl/CIOPPortalWAR/file/79758/Rownowaga-praca-zycie-materialu-informacyjne-IP15.pdf [dostęp: 05.03.2019]. https://popgym.pl/crossfit-definicja/ [dostęp: 02.03.2019].

https://sportowefakty.wp.pl/maraton/713440/nie-boj-sie-smierci-w-maratonie-ale-tez-nie-kus-losu-eksperci-radza-badaj-sie-i- [dostęp: 10.03.2019].

Jagas J., 1989, Czynnik ludzki w systemie czynników wydajności pracy „ „Ruch Prawniczy, Ekonomiczny i Socjologiczny", t. LI, z. 3.

Jastrzębski Z., 2007, Testy i próby wysiłkowe stosowane do oceny wydolności i sprawności fizycznej zawodników zespołowych gier sportowych [w:] Z. Jastrzębski (red.), Diagnostyka wytrenowania zawodników różnych dyscyplin sportowych, Olecko.

Jurek S., 2012, Jedz i biegaj. Niezwykła podróż do świata ultramaratonów i zdrowego odżywiania, Łódź. Jurek S., 2018, Północ. Jak odnalazłem siebie na Szlaku Appalachów, Łódź.

Kaczmarek J., Łepkowski W., Zdrodowski B. (red.), 2008, Słownik terminów z zakresu bezpieczeństwa narodowego, s. 15, http://mkuliczkowski.pl/static/pdf/slownik.pdf, [dostęp: 27.12.2018],.

Kapler A., Dodziuk L., 2007, Uzależniony człowiek, Warszawa.

Knapik A., Saulicz E., Plinta R., Kuszewski M., 2011, Aktywność fizyczna a zdrowie kobiet w starszym wieku, "Orthopaedic and Trauma Surgery", No. 6 (26);

Knapik A., Saulicz E., Plinta R., Miętkiewicz-Ciepły E. ", 2005, Wpływ systematycznej aktywności ruchowej na sprawność funkcjonalną kręgosłupa na podstawie trójpłaszczyznowego pomiaru zakresu gibkości, „Annnales Academiae Medicae Silesiensis, No. 59 (6).

Kochański B., Kałużna A., Kałużny K., Wołowiec Ł., Zukow W., Hagner W., 2015, Zespół przetrenowania w sporcie - mechanizm, objawy, przyczyny ,,Journal of Education, Health and Sport", Vol. 5, No 10. Kołodziej A., 2015, O potencjale i kierunkach rozwoju socjologii sportu, OPuscula Sociologica”, Szczecin, $\mathrm{nr} 2$ (12).

Kompała D., 2015, Pojmowanie bezpieczeństwa narodowego „,Obronność. Zeszyty Naukowe”, nr 3(15). Kopczewski M., 2013, Bezpieczeństwo wewnętrzne państwa - wybrane elementy, „Doctrina Studia Społeczno-Polityczne", nr 10.

Korzeniowska E., 1997, Zachowania i świadomość zdrowotna w sferze pracy, Łódź.

Koziej S., 2011, Bezpieczeństwo: istota, podstawowe kategorie i historyczna ewolucja „Bezpieczeństwo Narodowe", nr 18.

Kozłowska E., Marzec A., Kalinowski P., Bojakowska U., 2016, Koncepcja zdrowia i jego ochrony w świetle literatury przedmiotu, ,Journal of Education, Health and Sport", nr 6(9).

Krawczyk D., 2015 , Bezpieczeństwo wewnętrzne Państwa Polskiego. Rodzaje i źródła zagrożeń,,,Horyzonty Bezpieczeństwa", nr 1 (1).

Lelonek-Kuleta B., 2015, Uzależnienia behawioralne na tle współczesnej wiedzy o uzależnieniach ,„,Studia Społeczne", $\mathrm{nr} 12$ (1);

Leszczyński M., 2011, Bezpieczeństwo społeczne a współczesne państwo, „Zeszyty Naukowe Akademii Marynarki Wojennej", t. LII, nr 2 (185).

Lewandowska A., Ratuszek-Sadowska D., Hoffman J., Hoffman A., Kuczma M., Landowski L., Hagner W., 2017, Czynniki ryzyka i najczęstsze urazy narzq̨du ruchu u osób uprawiających biegi długodystansowe, ,Journal of Education, Health and Sport", nr 7(8). 
Lipowski M., 2006, Rekreacja ruchowa kobiet jako zachowanie prozdrowotne - uwarunkowania a motywy uczestnictwa, Gdańsk.

Loranty K., 2007, Bezpieczeństwo społeczne państwa demokratycznego „,Zeszyty Naukowe AON”, nr 1; Machelski Z., 2005, Wprowadzenie do polityki społecznej, Opole.

Majer P., W poszukiwaniu uniwersalnej definicji bezpieczeństwa wewnętrznego, www.abw.gov.pl/download/1/1756/Majer.pdf [dostęp 27.12.2018].

Makowiec-Dąbrowska T. ,2012, Wpływ aktywności fizycznej w pracy i życiu codziennym na układ krqżenia, „Forum Medycyny Rodzinnej”, t. 6, nr 3.

Malińska M., 2017, Skuteczność programów interwencyjnych promujących aktywność fizycznq w miejscu pracy, "Medycyna Pracy", nr 68 (2).

Marchewka A., Jungiewicz M., 2008, Aktywność fizyczna w młodości a jakość życia w starszym wieku, "Gerontologia Polska", t. 16, nr 2.

Maslow A., 2009, Motywacja i osobowość, Warszawa.

McAuley P.A. , Artero E.G., Sui X., Lavie C.J., Almeida M.J., Blair S.N., 2014, Fitness, fatness and survival in adults with prediabetes, "Diabetes Care", No. 37 (2);

Mickiewicz P., 2018, System bezpieczeństwa narodowego w rozwiązaniach systemowych wybranych państw, Warszawa.

Mynarski W., Rozpara M., Królikowska B., Puciato D., Graczykowska B., 2012, Jakościowe i ilościowe aspekty aktywności fizycznej, Opole.

National Center for Chronic Disease Prevention and Health Promotion, 2019, https://www.cdc.gov/ physicalactivity/about-physical-activity/why-it-matters.html [dostęp: 03.09.2019].

Nazar K., 2001, Czynność układu krążenia podczas wysiłku [w:] J. Górski (red.), Fizjologiczne podstawy wysiłku fizycznego, Warszawa.

Nazar K., 2001, Czynność układu oddechowego podczas wysiłku [w:] J. Górski (red.), Fizjologiczne podstawy wysiłku fizycznego, Warszawa.

Nazar K., Kaciuba-Uściłko H., 2001, Znaczenie aktywności ruchowej w zapobieganiu chorobom cywilizacyjnym [w:] J. Górski (red.), Fizjologiczne podstawy wysiłku fizycznego, Warszawa.

Nowak P. F., 2010, Aktywność fizyczna oraz inne zachowania zdrowotne w stylu życia menedżerów, Opole. Ostrowska A., 1999, Styl życia a zdrowie. Z zagadnień promocji zdrowia, Warszawa.

Ostrowska-Dołęgowska M., 2017, https://mojekoniki.wordpress.com/2017/07/01/czesc-bulimio/\#more-3269 [dostęp: 06.03.2019].

Pilaczyńska-Szczęśniak Ł, Celichowski J., 2001, Wpływ wysiłku fizycznego na mięśnie szkieletowe [w:] J. Górski (red.), Fizjologiczne podstawy wysiłku fizycznego, Warszawa.

Posłuszny M., Lapina S., 2011, Rekreacja jako sposób wzmacniania układu krążenia człowieka, „Studia Peregietica", nr 6.

Powell K.E., Paluch A.E., Blair S.N., 2011, Physical activity for health: What kind? How much? How intense? On top of what?, "Annual Review of Public Health", Vol. 32.

President's Council on Sports, Fitness \& Nutrition, 2017, https://www.hhs.gov/fitness/be-active/ importance-of-physical-activity/index.html [dostęp: 03.09.2019].

Rudawska I., 2013, Obciq̨zenie gospodarki chorobami przewlekłymi - problem nie tylko ochrony zdrowia, "Ekonomia/ Uniwersytet Warszawski”, nr 32.

Sankowski T., 2001, Wybrane psychologiczne aspekty aktywności sportowej, http://www.wbc.poznan. pl/Content/1553/index.html\#IDAOIC3E, 2001 [dostęp: 28.02.2019]. 
Sheridan C.L., Radmacher S.A., 1998, Psychologia zdrowia. Wyzwanie dla biomedycznego modelu zdrowia, Warszawa.

Skarżyński J., 2015, Biegiem przez życie, Szczecin.

Spustek H., Paluch A., 2017, Struktura systemu bezpieczeństwa narodowego Polski, ,Zeszyty Naukowe Politechniki Śląskiej" Seria: Organizacja i Zarządzanie, z. 100.

Starzyńska-Kościuszko E. , 2010, Holistyczna (całościowa) koncepcja zdrowia: zdrowie jako wartość, „Humanistyka i Przyrodoznawstwo", nr 16.

Stempień J.R., 2016, Wartość poznawcza kulturowej kliszy "samotnego długodystansowca” [w:] B. Wiśniewska-Paź, P. Wróblewski (red.), Społeczeństwo - Sport-Edukacja, Katowice.

Toczek M.J., Bezpieczeństwo państwa, bezpieczeństwo narodowe., http://www.klubinteligencjipolskiej.pl/2015/05/bezpieczenstwo-panstwa-bezpieczenstwo-narodowe</htm [dostęp: 27.12.2018]. Walczak M., Tomczak M., 2011, Poczucie jakości życia jako efekt zaspokojenia potrzeb psychologicznych i zróżnicowania motywacji do aktywności fizycznej, ,Zeszyty Naukowe Uniwersytetu Szczecińskiego" nr 689 „Ekonomiczne problemy usług", nr 78.

Wojtasik W., Szulc A., Kołodziejczyk M., Szulc A., 2015, Wybrane zagadnienia dotyczące wpływu wysitku fizycznego na organizm człowieka, ,Journal of Education, Health and Sport”, No. 5(10);

Woynarowska B., 2007, Edukacja zdrowotna. Podręcznik akademicki, Warszawa.

Woźniak M., Brukwicka I., Kopański Z., Kollár R., Kollárová M., Bajger B., 2015, Zdrowie jednostki i zbiorowości, "Journal of Clinical Healthcare", No. 4.

Zięba R., Zając J., 2010, Budowa zintegrowanego systemu bezpieczeństwa narodowego Polski - Ekspertyza, http://www.pl.ism.uw.edu.pl/wp-content/uploads/2013/02/zieba-zajac-budowa_zintegrowanego_systemu_bezpieczenstwa_narodowego_polski_ekspertyza_2010.pdf [dostęp: 04.03.2019].

Żukowska Z., 2008, Aktywność fizyczna w prozdrowotnym stylu życia współczesnego człowieka [w:] A. Kaźmierczak, A. Maszorek-Szymali, A. Dębowska (red.), Kultura fizyczna i zdrowotna współczesnego człowieka. Teoretyczne podstawy i praktyczne implikacje, Łódź.

\section{Akty prawne i dokumenty}

Hierarchia zasadniczych narodowych dokumentów dotyczących obronności, https://www.bbn.gov. pl/ftp/dok/01/hierarchia_dokumentow_dotyczacych_obronnosci_pazdziernik_2013.pdf [dostęp: 25.02.2019].

Polska 2030. Trzecia fala nowoczesności. Długookresowa strategia rozwoju kraju, 2013.

Strategia bezpieczeństwa narodowego Rzeczypospolitej Polskiej, 2007.

Strategia bezpieczeństwa narodowego Rzeczypospolitej Polskiej, 2014.

Strategia rozwoju kraju 2020.

\section{Biogram}

kukasz Bień - absolwent studiów z zakresu bezpieczeństwa narodowego na Uniwersytecie Gdańskim. Jego zainteresowania badawcze dotyczą bezpieczeństwa narodowego w aspekcie społecznym i ideologicznym w zakresie interdyscyplinarnym. 